\title{
Ethylene Synthesis and Sensitivity in Crop Plants
}

\author{
Stephen P. Klassen and Bruce Bugbee ${ }^{1}$ \\ Crop Physiology Laboratory, Department of Plants, Soils and Biometeorology, Utah State University, Logan, UT 84322-4820
}

Closed and semi-closed plant growth chambers have long been used in studies of plant and crop physiology. These studies include the measurement of photosynthesis and transpiration via photosynthetic gas exchange. Unfortunately, other gaseous products of plant metabolism can accumulate in these chambers and cause artifacts in the measurements. The most important of these gaseous byproducts is the plant hormone ethylene $\left(\mathrm{C}_{2} \mathrm{H}_{4}\right)$. In spite of hundreds of manuscripts on ethylene, we still have a limited understanding of the synthesis rates throughout the plant life cycle. We also have a poor understanding of the sensitivity of intact, rapidly growing plants to ethylene. We know ethylene synthesis and sensitivity are influenced by both biotic and abiotic stresses, but such whole plant responses have not been accurately quantified. Here we present an overview of basic studies on ethylene synthesis and sensitivity.

\section{Ethylene Sensitivity}

An analysis of ethylene sensitivity should start with a review of ambient levels. The technically correct SI unit for gas concentration in air is the mole fraction, expressed as moles of gas per mole of air $\left(\mathrm{mol} \cdot \mathrm{mol}^{-1}\right)$. One $\mathrm{ppm}$ of a gas equals one micromole per mole of air, and one ppb equals one nanomole per mole of air (Table 1).

Abeles (1992) cites ethylene levels have been reported as high as $500 \mathrm{nmol} \cdot \mathrm{mol}^{-1}(500 \mathrm{ppb})$ in California and $700 \mathrm{nmol} \cdot \mathrm{mol}^{-1}(700 \mathrm{ppb})$ in Washington D.C., primarily attributed to automobile exhaust. We have been continuously monitoring the ethylene concentration in the air above the Utah State University Research Greenhouse in Logan, Utah, for the past 2 years. Levels are typically below the detectable limit of our gas chromatograph (about $1 \mathrm{nmol} \cdot \mathrm{mol}^{-1}$ ), but during calm periods with increased traffic ( $7: 45$ to $8 \mathrm{Am}$ ) levels can increase to 1 to $2 \mathrm{nmol} \cdot \mathrm{mol}^{-1}$. These measurements suggest that crop plants in rural areas are exposed to levels that average $<1 \mathrm{nmol} \cdot \mathrm{mol}^{-1}$ from anthropogenic ethylene emissions. Biogenic emissions of ethylene from intensive agricultural areas could expose crops to much higher levels of ethylene if the rate of synthesis was high and turbulent mixing with the atmosphere was limited. However, atmospheric turbulence on even calm days is sufficient to keep ethylene levels within about 3 $\mathrm{nmol} \cdot \mathrm{mol}^{-1}$ of ambient even during periods of peak ethylene synthesis from stressed crops (assuming a high production rate of $10 \mathrm{nmol}$ per $\mathrm{kg}$ per second). Our calculations suggest that the biogenic contribution to ethylene levels in the air around unstressed plants would be less than $0.03 \mathrm{nmol} \cdot \mathrm{mol}^{-1}$ with a slight breeze.

Levels from 50 to $100 \mathrm{nmol} \cdot \mathrm{mol}^{-1}$ are common in greenhouses with heating or ventilation problems and have caused a broad range of crop damage in the horticulture industry (Blankenship and Kemble, 1996; Gibson et al., 2000; Mortensen, 1989). North Carolina State University provides helpful information on how to prevent $\mathrm{C}_{2} \mathrm{H}_{4}$ problems in greenhouses and a service for checking air samples posted on the web at www.ces.ncsu.edu/depts/hort/greenhouse_veg/ . Levels as high as $1000 \mathrm{nmol} \cdot \mathrm{mol}^{-1}$ have been measured in controlled environments in both ground and space studies (Abeles et al., 1992; Salisbury, 1997; James et al., 1998). Elevated $\mathrm{C}_{2} \mathrm{H}_{4}$ levels can cause a variety of abnormal responses including shortened height, epinasty, leaf rolling, premature leaf senescence, and sterility (Abeles et al., 1992; Bennet and Hughes, 1972; Morison and Gifford, 1984).

Elevated $\mathrm{C}_{2} \mathrm{H}_{4}$ levels are of particular concern in tightly sealed bioregenerative life support systems, which are being developed for space by the National Aeronautics and Space Administration (NASA). The objectives of a bioregenerative life support system are to provide

Work supported by the National Aeronautics and Space Administration Advanced Life Support Program and by the Utah State Agricultural Experiment Station, Utah State Univ. Approved as journal paper No. 7643.

${ }^{1}$ Corresponding author; e-mail bugbee@ cc.usu.edu. food, $\mathrm{O}_{2}$ replenishment, $\mathrm{CO}_{2}$ removal, and water purification for long term space exploration. NASA has recognized that atmospheric $\mathrm{C}_{2} \mathrm{H}_{4}$ may need to be scrubbed to prevent abnormal plant growth in space. Attempts at achieving normal plant growth and reproduction in the microgravity conditions of spaceflight have been plagued by problems associated with the gaseous environment (Musgrave et al., 1997). Elevated ethylene has been implicated as the cause of abnormal plant growth (roots, shoots, yield) in numerous spaceflight experiments (James et al., 1998; Kiss et al., 1998, 1999; Levinskikh et al., 2000; Salisbury, 1997). Recent advances in catalytic scrubbing technology have significantly improved our ability to remove $\mathrm{C}_{2} \mathrm{H}_{4}$ from air (Tibbitts et al., 1998). However, it is difficult to remove $\mathrm{C}_{2} \mathrm{H}_{4}$ below 50 $\mathrm{nmol} \cdot \mathrm{mol}^{-1}$ in closed plant growth chambers and this is still 10 to 50 times higher than levels in the field.

The threshold for ethylene sensitivity. A thorough understanding of the threshold concentration below which ethylene has no effect is imperative to eliminating ethylene effects in ground based research, greenhouse production, and in the microgravity environment of spaceflight. Abeles (1992) suggested threshold values of $100 \mathrm{ppb}$ for acute exposure and $50 \mathrm{ppb}$ for chronic exposure and these values have been cited by other authors (e.g., Stutte, 1999). Unfortunately, these threshold concentrations are rough estimates based on incomplete studies. Our studies indicate that many crops are sensitive to chronic ethylene levels of 10 to $25 \mathrm{nmol} \cdot \mathrm{mol}^{-1}$ (Figs. 1 and 2). These studies were done in flow-through growth chambers using state of the art, continuous monitoring instrumentation (Klassen and Bugbee, 2001).

Genetic and environmental interactions with ethylene sensitivity. There is considerable genetic variability in $\mathrm{C}_{2} \mathrm{H}_{4}$ sensitivity. Variation in post harvest flower longevity among carnations has been attributed to genetic variation in both $\mathrm{C}_{2} \mathrm{H}_{4}$ synthesis and perception (Wu et al., 1991; Brandt and Woodson, 1992). We observed significant differences in the ethylene sensitivity of closely related wheat cultivars (Klassen and Bugbee, 2001). Recent advances in the identification of genes associated with $\mathrm{C}_{2} \mathrm{H}_{4}$ perception facilitate breeding for $\mathrm{C}_{2} \mathrm{H}_{4}$ tolerance (Barry et al., 2000; Bleecker and Kende, 2000; Bleecker and Schaller, 1996; Gubrium et al., 2000; Lindstrom et al., 1999; Klee, 2002).

Ethylene insensitive transgenic tomatoes, petunias, and tobacco have been developed by insertion of a mutant Arabidopsis etr1-1 gene (Wilkinson et al., 1997). However, $\mathrm{C}_{2} \mathrm{H}_{4}$ insensitive Arabidopsis mutants and transgenic plants can have abnormal developmental processes that affect seed germination, flower initiation, flower longevity, and fruit set (Bleecker et al., 1988; Gubrium et al., 2000; Klee and Clark, 2002).

In addition to genetics, environmental factors including light, temperature, $\mathrm{O}_{2}$, and $\mathrm{CO}_{2}$ concentrations influence $\mathrm{C}_{2} \mathrm{H}_{4}$ production (Abeles et al., 1992; Finlayson and Reid, 1996; Grodzinski and Woodrow, 1989; Preger and Gepstein, 1984; Sanders et al., 1990; Sisler and Wood, 1988). How these factors influence $\mathrm{C}_{2} \mathrm{H}_{4}$ perception is not well understood. Burg and Burg (1967) classified hypoxia $\left(<5 \% \mathrm{O}_{2}\right)$ as an inhibitor of $\mathrm{C}_{2} \mathrm{H}_{4}$ responses, but later studies found no effect of hypoxia on $\mathrm{C}_{2} \mathrm{H}_{4}$ binding activities in plants (Sanders et al., 1990). In some plants, root-zone waterlogging and the resulting hypoxia have been shown to lead to the build-up of ethylene in root tissue. The trapped ethylene stimulates cellulase and pectinase production resulting in the breakdown of cell walls ultimately leading to the formation of aerenchyma passages (Moore et al., 1998).

Gubrium et al. (2000) observed significant differences between the

Table 1. Units for gas concentrations commonly found in the literature.

\begin{tabular}{lcc}
\hline $\begin{array}{l}\text { SI } \\
\text { units }\end{array}$ & $\begin{array}{c}\text { Volumetric } \\
\text { units }\end{array}$ & $\begin{array}{c}\text { Unitless } \\
\text { ratios }\end{array}$ \\
\hline $1 \mu \mathrm{mol} \cdot \mathrm{mol}^{-1}$ & $1 \mu \mathrm{L} \cdot \mathrm{L}^{-1}$ & $1 \mathrm{ppm}$ \\
$1 \mathrm{nmol} \cdot \mathrm{mol}^{-1}$ & $1 \mathrm{~nL} \cdot \mathrm{L}^{-1}$ & $1 \mathrm{ppb}$ \\
$1 \mathrm{pmol} \cdot \mathrm{mol}^{-1}$ & $1 \mathrm{pL} \cdot \mathrm{L}^{-1}$ & $1 \mathrm{ppt}$ \\
\hline
\end{tabular}




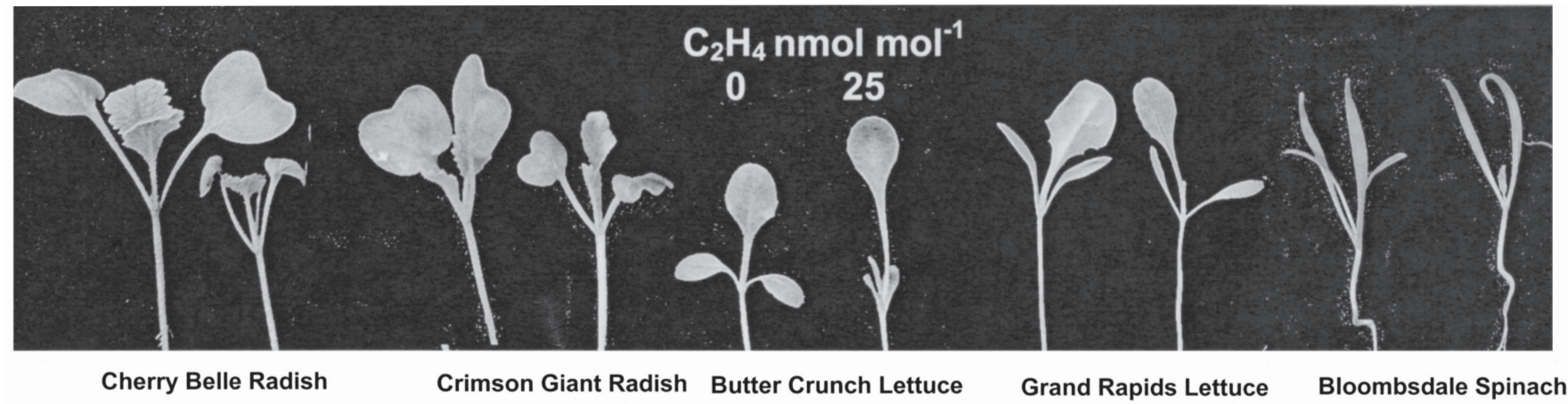

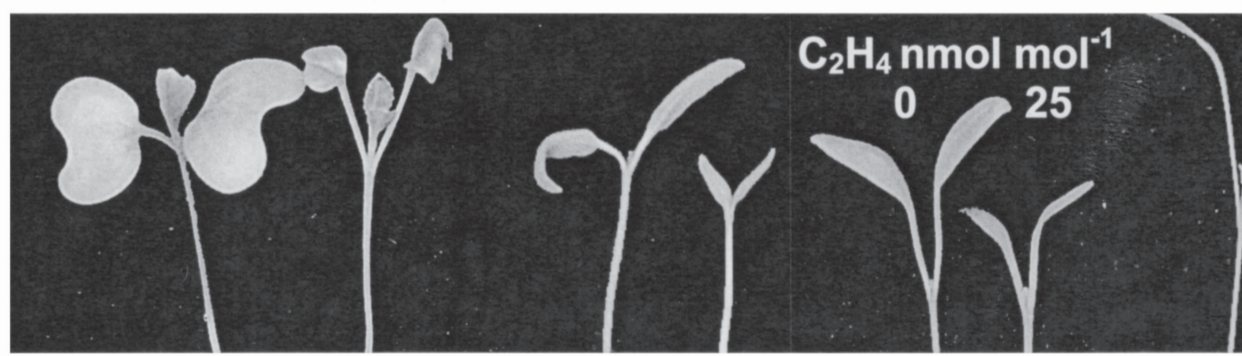

Golden Acre Cabbage

Reimann Philip Tomato

Fordhook Chard
Nantes Carrot

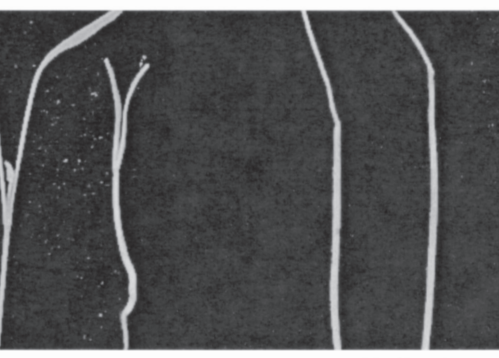

Sweet Spanish Green Onion

Fig. 1. A comparison of week old seedlings germinated in either clean air (left) or $25 \mathrm{nmol} \cdot \mathrm{mol}^{-1}$ ethylene (right). Typical responses included curled and stunted cotyledons, stunted first leaves, and etiolated petioles in lettuce.

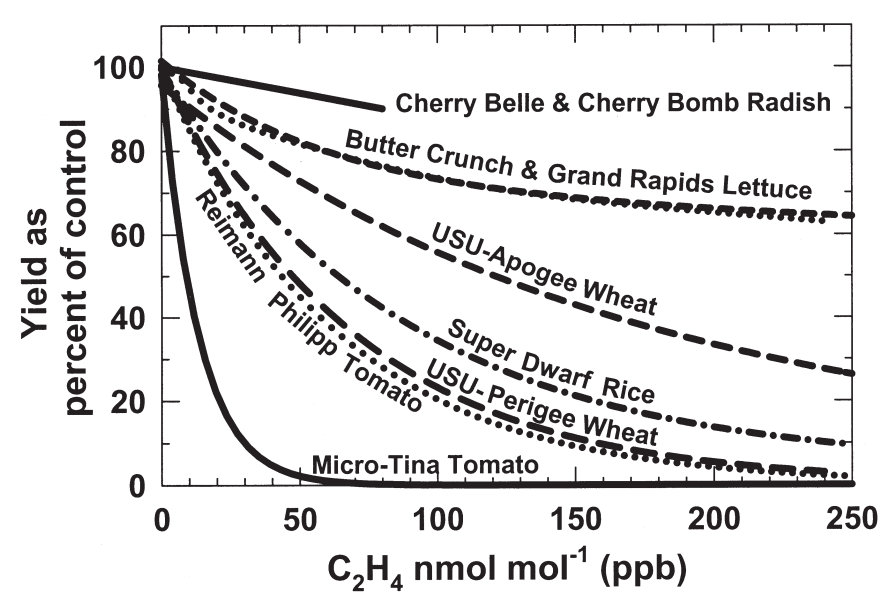

Fig. 2. (above) The effect of ethylene on the yield of radish, lettuce, tomato, wheat, and rice. Yields are as fresh weight for radish, lettuce, and tomato and dry seed weight for wheat and rice.

temperature responses of insensitive transgenic petunias and wild-type plants, suggesting a possible interaction between temperature and $\mathrm{C}_{2} \mathrm{H}_{4}$ perception. We found that ethylene sensitivity decreased with increasing temperature in wheat (Fig. 3). As a gas, the water solubility of $\mathrm{C}_{2} \mathrm{H}_{4}$ decreases with increasing temperature. Therefore, lower cytoplasmic $\mathrm{C}_{2} \mathrm{H}_{4}$ concentrations would occur at a higher temperature compared to a lower temparature for a given atmospheric $\mathrm{C}_{2} \mathrm{H}_{4}$ concentration. This effect may contribute to reduced sensitivity with increasing temperature. However, based on the Ostwald coefficient for the partitioning of $\mathrm{C}_{2} \mathrm{H}_{4}$ between gas and water, the cytoplasmic concentration only decreases about $0.25 \%$ per $1{ }^{\circ} \mathrm{C}$ between 15 and $23{ }^{\circ} \mathrm{C}$ or $2 \%$ over this temperature range (Sisler, 1991). Previously

Fig. 3. Effect of temperature on ethylene sensitivity in two closely related wheat cultivars. we showed that ethylene inhibited anther dehiscence in wheat and we now hypothesize that warmer temperatures promote dessication of the anthers, improving pollination in ethylene exposed plants (Campbell et al., 2001).

Carbon dioxide is of particular interest since it is abnormally high in space environments (1\% to $2 \%$ ) and is commercially used in fruit storage to inhibit the ripening action of $\mathrm{C}_{2} \mathrm{H}_{4}$ (Yang, 1985). Burg and Burg (1967) reported that $\mathrm{CO}_{2}$ competitively inhibits $\mathrm{C}_{2} \mathrm{H}_{4}$ action, but only at very high levels (10\%). Later studies suggested the inhibitory effects of $\mathrm{CO}_{2}$ are non-competitive (Sisler, 1979; Sanders et al., 1990). We found no interaction between elevated $\mathrm{CO}_{2}(1200$ and $5000 \mathrm{mmol} \mathrm{CO} / \mathrm{mol})$ and ethylene sensitivity in wheat (Klassen and Bugbee, 2001).

\section{Ethylene Synthesis}

Healthy plants synthesize ethylene to mediate developmental stages from germination to senescence. Despite the extensive literature on organ and tissue ethylene production, rates of whole plant synthesis are not well

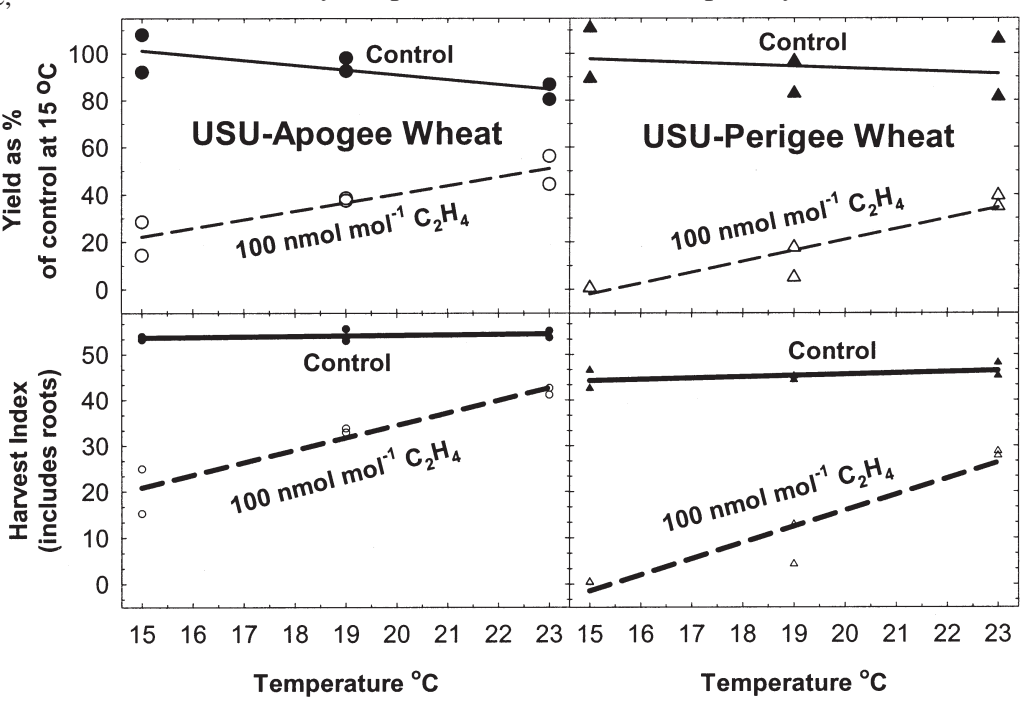




\begin{tabular}{|c|c|c|c|c|c|c|c|}
\hline Plant & Tissue & $\begin{array}{l}\mathrm{C}_{2} \mathrm{H}_{4} \\
\text { production } \\
\text { (nmol } \cdot \mathrm{kg}^{-1} \cdot \mathrm{s}^{-1} \\
\text { dry wt) }\end{array}$ & Method & $\begin{array}{l}\operatorname{Time}^{y} \\
\text { (h) }\end{array}$ & $\begin{array}{l}\operatorname{Light}^{\mathrm{x}} \\
\left(\mu \mathrm{mol} \cdot \mathrm{m}^{-2} \cdot \mathrm{s}^{-1}\right)\end{array}$ & $\begin{array}{l}\text { Stress or } \\
\text { conditions }\end{array}$ & Reference \\
\hline Cucumber & Root & 0.2 & Headspace & $1-2$ & Dark & Control & Romera et al., 1999 \\
\hline Cucumber & Root & $0.3-0.4$ & Headspace & $1-2$ & Dark & Low Fe & Romera et al., 1999 \\
\hline Green bean & Whole seedling & 0.1 & Open flow & & 150 & & Weckx and Van Poucke, 1989 \\
\hline Lettuce & Canopy & 0.2 & Estimated & & & & Wheeler et al., 1996 \\
\hline Pea & Stem & $0.01-0.1$ & Headspace & & Dark & Etoliated & Burg and Burg, 1968 \\
\hline Pea & Root & 0.3 & Headspace & 2 & & Control & Bertell et al., 1990 \\
\hline Pea & Root & 1.1 & Headspace & 2 & & Light-exposed roots & Bertell et al., 1990 \\
\hline Rice & Leaf & $0.1-0.7$ & Headspace & 3 & & Control & Yamauchi and Peng, 1995 \\
\hline Rice & Root & $0.2-0.6$ & Headspace & & & Control & Yamauchi and Peng, 1995 \\
\hline Rice & Leaf & $0.9-1.8$ & Headspace & & & High Fe & Yamauchi and Peng, 1995 \\
\hline Rice & Leaf & 0.5 & Headspace & 2 & Dark & Control & Peng and Yamauchi, 1993 \\
\hline Rice & Leaf & 7.3 & Headspace & 2 & Dark & High Fe & Peng and Yamauchi, 1993 \\
\hline Soybean & Whole seedling & 0.4 & Open flow & & Dark & & Weckx and Van Poucke, 1989 \\
\hline Soybean & Whole seedling & 0.8 & Open flow & & 100 & & Weckx and Van Poucke, 1989 \\
\hline Spinach & Leaf laminae & $0.3-0.6$ & Headspace & 24 & 100 & & Crevecoeur et al., 1986 \\
\hline Spinach & Petiole & 1.3 & Headspace & 24 & 100 & & Crevecoeur et al., 1986 \\
\hline Spinach & Whole plant & 0.1 & Headspace & 24 & 100 & & Crevecoeur et al., 1986 \\
\hline Tomato & Whole plant & 14.1 & Headspace & 24 & 50 & High $\mathrm{NH}_{4}$ & Corey et al., 1987 \\
\hline Tomato & Whole plant & 2.1 & Headspace & 24 & 50 & Control & Corey et al., 1987 \\
\hline Tomato & Leaf & 0.6 & Headspace & & & High $\mathrm{H}_{2} \mathrm{O}$ & Basiouny et al., 1994 \\
\hline Tomato & Leaf & 0.5 & Headspace & & & Low $\mathrm{H}_{2}^{2} \mathrm{O}$ & Basiouny et al., 1994 \\
\hline Tomato & Leaf & 0.4 & Headspace & & & Control & Basiouny et al., 1994 \\
\hline Tomato & Root & 0.7 & Headspace & 2 & Dark & Control & Romera et al., 1999 \\
\hline Tomato & Root & $1.4-2.5$ & Headspace & 2 & Dark & Low $\mathrm{Fe}$ & Romera et al., 1999 \\
\hline Wheat & Whole seedling & 0.3 & Open flow & & Dark & & Weckx and Van Poucke, 1989 \\
\hline Wheat & Whole seedling & 0.6 & Open flow & & 100 & & Weckx and Van Poucke, 1989 \\
\hline Wheat & Canopy & 0.1 & Estimated & & & & Wheeler et al., 1996 \\
\hline Wheat & Leaf & 0.8 & Headspace & 12 & & Seedling & Narayana et al., 1991 \\
\hline Wheat & Leaf & $0.3-0.5$ & Headspace & 12 & & 6 Weeks old & Narayana et al., 1991 \\
\hline Wheat & Root & 0.4 & Headspace & 2 & Dark & Control + Fe deficient & Romera et al., 1999 \\
\hline Wheat & Leaf & 0.3 & Headspace & 2 & & Control & Tonutti and Ramina, 1991 \\
\hline Wheat & Leaf & 3.8 & Headspace & 2 & & $\mathrm{O}_{2}$ stress & Tonutti and Ramina, 1991 \\
\hline Wheat & Root & 0.3 & Headspace & 2 & & Control & Tonutti and Ramina, 1991 \\
\hline Wheat & Root & 0.5 & Headspace & 2 & & $\mathrm{O}_{2}$ stress & Tonutti and Ramina, 1991 \\
\hline
\end{tabular}

${ }^{\mathrm{z}}$ Assuming dry weight is $10 \%$ of fresh weight.

${ }^{\mathrm{y}}$ Time in sealed vial before headspace analysis.

${ }^{x}$ Light level while in sealed vial.

characterized. Table 2 summarizes the literature on ethylene production by crop plants. A wide range of units has been used in the literature and rates have often been presented as per plant or per leaf making it difficult to extrapolate to whole plant communities. Only values that could be converted to moles per unit dry weight per second are listed. The commonly used headspace method calculates production rates based on the accumulation of ethylene in sealed containers. The time of incubation,

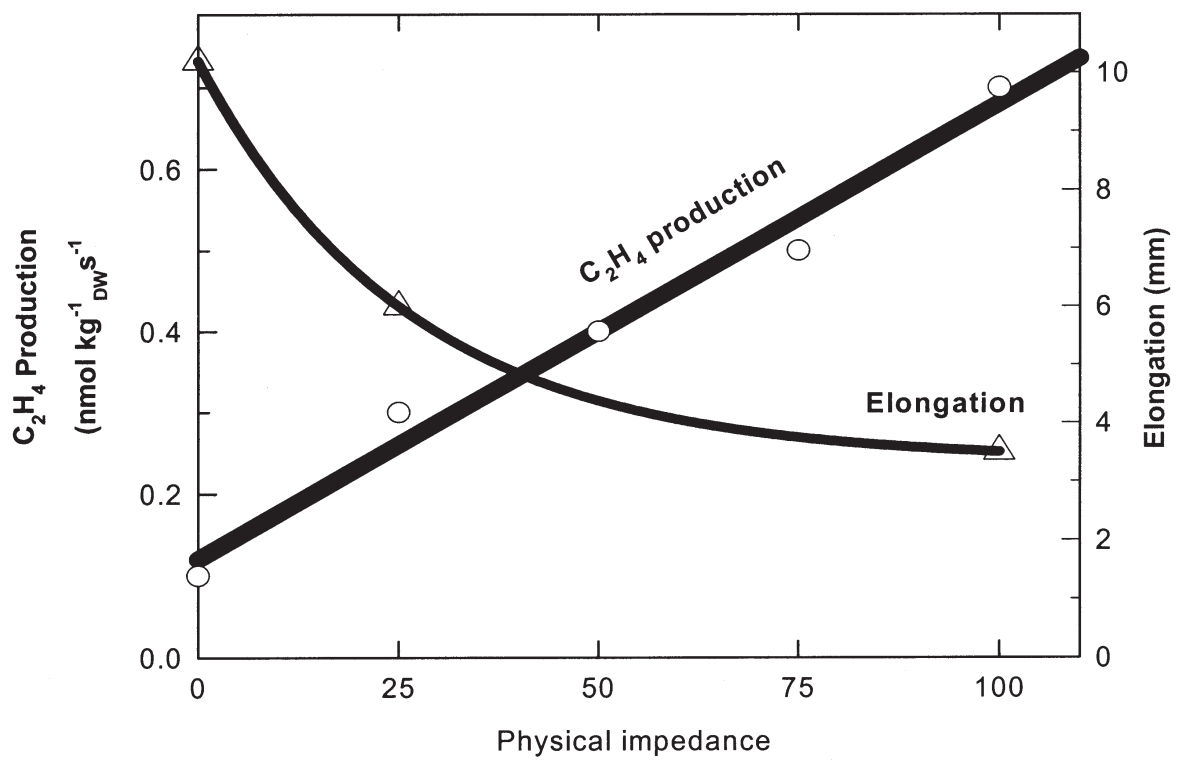

as applied pressure $(\mathrm{kPa})$ light level and experimental conditions are listed where possible.

The use of excised plant tissue and inadequate environmental control contributes to much of the confusion in the literature on rates of ethylene production. Of the 34 studies listed in Table 2, 27 measured ethylene synthesis from excised tissues in sealed containers. It is well known that mechanical perturbations and excision promote wound ethylene production (Abeles, 1992). Rates of ethylene production also vary with environmental conditions, which are often not adequately controlled in closed systems. Spencer (1989) tested the effect of light on ethylene production using excised tissues in a sealed vial and compared this to measurements of intact plants in a flow-through system. He found exactly opposite results between the two methods. The reason for this discrepancy was shown to be due to a drop in $\mathrm{CO}_{2}$ concentration in the sealed vials of tissue under the light (Kao and Yang, 1982). Finlayson and Reid (1996) demonstrated that excised roots respond differently to $\mathrm{CO}_{2}$ than intact plants and highlighted shortcomings of using excised tissues.

Investigations into the effects of water stress have also encountered problems with methodology. Morgan et al. (1990) showed that detached leaves react differently to drying than intact plants and this was verified by Narayana et al. (1991). Tong and Yang (1987) suggested that the

Fig. 4. Ethylene production and root elongation as a function of physical impedance in the growing medium (adapted from Sarquis et al., 1991). 
Table 3. Commonly used $\mathrm{C}_{2} \mathrm{H}_{4}$ inhibitors.

\begin{tabular}{ll}
\hline Synthesis & Action \\
inhibitors & inhibitors \\
\hline Aminoethoxyvinylglycine (AVG) & Silver thiosulfate (STS) \\
Aminooxyacidic acid (AOA) & 2,5-Norbornadiene (NBD) \\
L-canaline (CAN) & Methylcyclopropene (MCP) \\
Cobalt ions, Co(II) & Silver ion salts \\
\hline
\end{tabular}

temperature response of ethylene synthesis was also different between leaf discs and intact plants.

Many studies have examined root production of ethylene, but nearly all of them have used excised root tissue. Mechanical impedance of root elongation caused by tightly packed substrates can increase ethylene synthesis in roots (Sarquis, 1991). The rate of root ethylene production can differ significantly from ethylene in the shoots. Since there is minimal convective air movement in the root zone, the ethylene produced by roots must be dispersed by diffusion. Furthermore, germinating shoots have been shown to produce increased ethylene levels when encountering mechanical barriers prior to emergence (Schwarzbach et al., 1991). Thus, a root zone with high mechanical impedance can result in unusually high ethylene levels in the gas phase of the root zone. Independent, simultaneous measurements of root-zone ethylene production would therefore be highly useful.

Ethylene production rates can be 10 to 20 times higher in stressed plants. Environmental conditions that influence ethylene production include:

1. Carbon dioxide. Kao and Yang (1982) determined ethylene production in the light increases with increasing $\mathrm{CO}_{2}$ due to its promotion of 1-aminocyclopropane-1-carboxylic acid (ACC) oxidase activity, the rate-limiting enzyme responsible for the last step in ethylene synthesis.

2. Hypoxia. Bradford and Dilley (1978) demonstrated that hypoxia promotes ethylene production in the roots and shoots of tomato.

3. Drought. Xu and Qi (1993) found no effect of slowly developing drought stress on ethylene production, but that rapidly developing drought stress promoted ethylene production.

4. Temperature. Field and Barrowclough (1989) found that ethylene production increased with temperature.

5. Light. Gepstein and Thimann (1980) observed lower ethylene production rates in the light than in the dark in a variety of dicots and monocots.

6. Light quality. Vangronsveld et al. (1988) concluded that red light significantly reduced ethylene biosynthesis in etiolated bean seedlings.

7. Physical impedance. Morgan et al. (1993) demonstrated that increasing physical impedance of the rooting medium increases ethylene production by roots.

Root-zone hypoxia. Although the conversion of ACC to ethylene is oxygen dependent, hypoxia induced by flooding promotes the synthesis of ACC in the roots of tomato, which is transported to the shoots and rapidly oxidized to ethylene (Bradford and Yang, 1980). Hypoxia increased ethylene production in both roots and leaves of tomato resulting in leaf epinasty and chlorosis (Bradford and Dilley, 1978; Morgan and Drew, 1997). Similarly, hypoxia has been shown to increase endogenous ethylene concentrations in tissues of many crops including wheat, maize, rice and radish (Atwell et al., 1988; Kawase, 1972; Tonutti and Ramina, 1991). This response can be rapid. The ethylene production rate of wheat leaves doubled within $2 \mathrm{~h}$ of exposure to $10 \% \mathrm{O}_{2}$ in the root-zone (Tonutti and Ramina, 1991). Changes in production rates can be dramatic. Hypoxia increased ethylene synthesis up to 8 fold in roots and 15 fold in shoots (Atwell et al., 1988; Tonutti and Ramina, 1991). The difficulty of uniformly distributing water and air throughout the root zone in microgravity has made inadequate root-zone aeration a common stress.

Water stress. The literature on the effect of water stress on ethylene production is inconsistent. The discrepancies are largely due to inadequate experimental methodology. Studies involving the desiccation of detached leaves suggest water stress increases ethylene production but studies of intact plants suggest decreased ethylene synthesis (Morgan et al., 1990; Narayana et al., 1991). The current consensus is that the effect of water stress on ethylene synthesis depends on the rate at which the plants are stressed. Rapid induction of water stress promotes ethylene production and slow induction inhibits production (Morgan and Drew, 1997; Xu and Qi, 1993). Reduced ethylene production is expected in the field since drought stress typically occurs slowly. However, water stress occurs rapidly in highly porous media, especially if the rootzone volume is restricted. The rapid induction of water stress in these conditions would probably increase ethylene synthesis.

Root-zone mechanical impedance. Sarquis et al. (1991) tested the effect of physical impedance (simulated by applied pressure on a fritted clay rooting medium) on ethylene production in the roots of maize seedlings in a flow-through system. Ethylene production rates increased from 0.1 in the control to $0.3 \mathrm{nmol} \cdot \mathrm{kg}^{-1} \cdot \mathrm{s}^{-1}$ (dry weight) when a pressure of only $25 \mathrm{kPa}$ was applied, and then to $0.7 \mathrm{nmol} \cdot \mathrm{kg}^{-1} \cdot \mathrm{s}^{-1}$ (dry weight) at $100 \mathrm{kPa}$ after $10 \mathrm{~h}$ of treatment (Fig. 4). Root elongation was significantly inhibited. The effects of pressure on root elongation and radial expansion were similar to the effects of applied ethylene. When ethylene production in impeded roots was inhibited, elongation increased to $90 \%$ of the control, suggesting that ethylene causes the roots to overreact to the impedance.

High temperature stress. Ethylene synthesis typically increases with temperature, probably because the enzyme activity responsible for ethylene synthesis increases. Field (1981a, 1981b) found that ethylene production in bean leaf discs increased with temperature from 2.5 to $35{ }^{\circ} \mathrm{C}$. Above $35{ }^{\circ} \mathrm{C}$ production rates declined and reached a minimum at $45^{\circ} \mathrm{C}$. The ethylene production rate doubled [from 0.25 to $0.5 \mathrm{nmol} \cdot \mathrm{kg}^{-1} \cdot \mathrm{s}^{-1}$ (dry weight)] between 25 and $35^{\circ} \mathrm{C}$. These studies were based on excised tissue from plants grown at $25^{\circ} \mathrm{C}$ and incubated at various temperatures. An $18 \mathrm{~h}$ preincubation period was used to differentiate between basal and wound ethylene.

While trying to interpret differences between the temperature response of intact carnations and bean leaf discs, Field and Barrowclough (1989) specifically state that the method involving the use of bean leaf discs was designed to measure temperature induced changes in wound ethylene. Lurie et al. (1996) found heat shock temporarily reduced ethylene production in tomato leaves but Aloni et al. (1995) determined that the use of the ethylene action inhibitor silver thiosulfate (STS) reduced heat stress induced flower abscission in pepper. No studies have been found characterizing ethylene production rates as a function of temperature for intact plants.

Quantity and quality of photosynthetic radiation. Increasing light intensity has been shown to both increase and decrease ethylene production. Many earlier studies that implicated light as an inhibitor of ethylene production have since been discredited due to a lack of $\mathrm{CO}_{2}$ control (Grodzinski, 1984; Kao and Yang, 1982; Weckx and Van Poucke, 1989). Even when $\mathrm{CO}_{2}$ levels have been controlled, the effect of light intensity on ethylene production has been mixed. Grodzinski (1984) found little difference between light and dark rates of ethylene production in $\mathrm{C}_{3}$ plants but higher rates in the light in $\mathrm{C}_{4}$ plants. Others have reported that light increased ethylene production in a variety of monocots and dicots but did not test light levels higher than $150 \mu \mathrm{mol} \cdot \mathrm{m}^{-2} \cdot \mathrm{s}^{-1}$ (Knee et al., 2000; Weckx and Van Poucke, 1989). Bassi and Spencer (1983) reported that light had no effect on ethylene production by intact plants of tobacco, sunflower, soybean, and tomato in a flow-through system. The effect of light intensity on the ethylene production of intact plants throughout the life cycle has not been examined.

Light quality has also been shown to affect ethylene production both positively and negatively and is regulated in part by phytochrome (Finlayson et al., 1998; Vangronsveld et al., 1988; Corbineau et al., 1995). These studies all indicate a complex relationship between phytochrome and ethylene production that needs further study. How different light sources with different spectral characteristics (LED, fluorescent, HPS, and metal halide) affect ethylene production remains untested.

\section{Ethylene Mutants}

The identification rate of ethylene mutants has rapidly increased in the past decade. More than 20 ethylene mutants have been identified that are altered in their ability to synthesize, perceive, or respond to ethylene. The largest collection of mutant phenotypes exists for the model higher plant Arabidopsis thaliana. Additional ethylene mutants have been isolated for tomato, tobacco, and petunia. These mutants 
have been primarily used to elucidate the genes responsible for ethylene synthesis and perception, but the Arabidopsis collection of mutants also provides the opportunity to study the effect of environmental stress on ethylene synthesis and sensitivity.

Ethylene synthesis mutants. Ethylene synthesis mutants have reduced or eliminated capacity to synthesize ethylene. The enzyme ACC-synthase catalyzes the rate-limiting step in ethylene synthesis (Tarun et al., 1998) and ACC-oxidase catalyzes the formation of ethylene from ACC. Mutants without these enzymes produce minimal amounts of ethylene (Klee and Clark, 2002).

Ethylene perception mutants. Ethylene perception mutants fail to perceive ethylene. These mutants consist of members of the ethylene receptor gene family and their mutation results in a lack of ethylene binding to begin the signal transduction necessary to elicit hormonal response (Schaller and Bleecker, 1995; Sakai et al., 1998; Hua et al., 1998). The breeding lines with mutations in the genes ETR1-3, EIN21, and EIN4 are highly insensitive to atmospheric ethylene (Klee and Clark, 2002). Even in the presence of 10 ppm ethylene, these mutant genotypes have root and shoot elongation similar to wild-type in ethylene-free air (Roman et al., 1995).

Selective perception mutants. Ethylene elicits many developmental responses. Selective perception mutants have selectively altered ethylene responses. These mutants affect biochemical changes that are downstream from the initial ethylene binding. Some of these mutants lack one of the ethylene responses without affecting other responses. For example, the mutant eirl has a normal ethylene response in the shoot but lacks sensitivity in the roots, although the roots fail to respond to gravity (Roman et al., 1995). The so-called hook-less mutant (hlsl-1) lacks the typical ethylene triple response of seedlings, but has accelerated development with much earlier flowering than non-mutated plants (Guzman and Ecker, 1990).

Mutants may exist that are insensitive to ethylene during anthesis but respond to ethylene during all other stages of development. These mutants would reduce the likelihood of causing undesirable hormone interactions with gibberellic acid during germination, or auxin for gravitropism and phototropism. Unfortunately, mutants that fail to perceive or respond to ethylene typically produce more ethylene (Guzman and Ecker, 1990). This appears to occur as a result of a feedback response from a lack of ethylene perception. Using a double mutant that lacked the ability to both synthesize and perceive ethylene would reduce its sensitivity to atmospheric ethylene and minimize its own ethylene synthesis.

Disadvantages of ethylene mutants. Ethylene mutants often have altered rates of development. Flowering in Arabidopsis mutants is either earlier or slightly delayed depending on the mutant (Guzman and Ecker, 1990). Ethylene-insensitive petunias were found to have earlier flowering, delayed flower senesence, slightly reduced seed set, and delayed ripening (Gubrium et al., 2000). Smalle and Van Der Straeten (1997) reviewed the ethylene mutants and suggested that both ethyleneinsensitive and ethylene-synthesis mutants have normal development. They point out, however, that the normal ethylene responses to stress are critical to the survival of the plant. Several studies have indicated increased disease susceptibility for ethylene-insensitive mutants (Hoffman et al., 1999; Knoester et al., 1998; Thomma et al., 1999). Hoffman et al. (1999) suggest that ethylene insensitivity may increase disease susceptibility for some pathogens but decrease it for others.

\section{Ethylene Inhibitors}

In addition to genetic manipulations, ethylene synthesis and action can be controlled with the use of inhibitors. Numerous inhibitors have been identified and described (Abeles, 1992; Sisler and Serek, 1997). Those most commonly used in horticulture are listed in Table 3. Owens et al. (1971) found that rhizobitoxin, an amino acid secreted by microorganisms, inhibited $\mathrm{C}_{2} \mathrm{H}_{4}$ production. This led to the development of a synthetic analogue aminoethoxy-vinylglycine (AVG) and aminooxyacidic acid (AOA). Production inhibitors AVG, AOA, and 1-canaline (CAN) all inhibit the formation of ACC, the immediate precursor to ethylene (Abeles, 1992). AVG has recently become commercially available and is used for extending apple maturation and improving post-harvest quality. Cobalt ions are another commonly used inhibitor of $\mathrm{C}_{2} \mathrm{H}_{4}$ production and inhibit the final step in conversion of $\mathrm{ACC}$ to $\mathrm{C}_{2} \mathrm{H}_{4}$.

STS is highly xylem mobile and an effective action inhibitor but the mechanism of inhibition remains uncertain. Norbornadiene (NBD) is an effective competitive inhibitor that binds to the receptor. However, silver is a heavy metal, and NBD a possible carcinogen, so both these inhibitors are potentially hazardous. Methylcyclopropene (MCP) is also a competitive inhibitor. It exists as a gas, is non-toxic at active concentrations, and has been commercially available since 2002, making it the inhibitor of choice for regulating ethylene effects on fruits, vegetables, and flowers (Sisler and Serek, 1997). As with $\mathrm{C}_{2} \mathrm{H}_{4}$ mutants, the use of inhibitors has been found to alter plant growth and development, so caution must be used when interpreting experimental data.

\section{Conclusions}

Our studies suggest the threshold concentration for ethylene at which pollination and seed set are inhibited in both monocots and dicots is about $10 \mathrm{nmol} \cdot \mathrm{mol}^{-1}(10 \mathrm{ppb})$. The threshold concentration for inhibition of leaf expansion and vegetative growth is about $30 \mathrm{nmol} \cdot \mathrm{mol}^{-1}$ (30 ppb). How ethylene sensitivity interacts with the environment is not well documented. We found that elevated $\mathrm{CO}_{2}$ does not interact with ethylene sensitivity in wheat, but a warmer temperature was found to decrease ethylene-induced sterility in wheat. Genetic differences in sensitivity exist between species and among closely related cultivars. The interaction between genetic and environmental differences needs further study.

Reported rates of synthesis range 20 -fold from 0.1 to $2.0 \mathrm{nmol} \cdot \mathrm{kg}^{-1} \cdot \mathrm{s}^{-1}$ (dry weight) in roots and shoots of healthy plants. We know that ethylene production increases in response to plant stress and that the results of many studies have been confounded by the use of excised tissues and inadequate environmental control. Clearly, studies on ethylene synthesis are best conducted with flow-through systems on intact plants. To date, few studies with strict controls have used flow-through systems due to the difficulty of accurately measuring low levels of ethylene.

Recent advances in air monitoring technology such as the advent of systems for automated thermal desorption greatly simplify and improve the capability for direct analysis of low ethylene concentrations in air. This instrumentation can be integrated with multiple chamber flowthrough systems that have traditionally been used for gas exchange studies. The Crop Physiology Laboratory at Utah State University is currently setting up such a system to characterize whole plant basal and stress-induced ethylene synthesis rates throughout the life cycle of mutant and wild-type plants. The characterization of ethylene mutants and inhibitors will also provide us with powerful techniques for controlling $\mathrm{C}_{2} \mathrm{H}_{4}$ synthesis and sensitivity in closed environments.

\section{Literature Cited}

Abeles, F.B., P.W. Morgan, and M.S. Saltveit, Jr. 1992. Ethylene in plant biology. Academic Press, New York.

Aloni, B., L. Karni, and I. Rylski. 1995. Inhibitions of heat induced pepper (Capsicum аппиит) flower abscission and induction of fruit malformation by silver thiosulfate. J. Hort. Sci. 70:215-220.

Atwell. B.J., M.C. Drew, and M.B. Jackson. 1988. The influence of oxygen deficiency on ethylene synthesis, 1-aminocyclopropane-1-carboxylic acid levels and aerenchyma formation in roots of Zea mays. Physiol. Plant. $72: 15-22$.

Barry, C.S., M.I. Llop-Tous, and D. Grierson. 2000. The regulation of 1-aminocyclopropane-1-carboxylic acid synthase gene expression during the transition from system-1 to system-2 ethylene synthesis in tomato. Plant Physiol. 123:979-986.

Basiouny, F.M., K. Basiouny, and M. Maloney. 1994. Influence of water stress on abscisic acid and ethylene production in tomato under different PAR levels. J. Hort. Sci. 69:535-541.

Bassi, P.K. and M.S. Spencer. 1983. Does light inhibit ethylene production in leaves? Plant Physiol. 73:758-760.

Bennet, M.D. and W.G. Hughes. 1972. Additional mitosis in wheat pollen induced by etherel. Nature 240:566-568.

Bertell, G., E. Bolander, and L. Eliasson. 1990. Factors increasing ethylene production enhance the sensitivity of root growth to auxins. Physiol. Plant. 79:255-258

Blankenship S.M., and J. Kemble. 1996. Growth, fruiting and ethylene binding of tomato plants in response to chronic ethylene exposure. J. Hort. Sci. $71: 65-69$. 
Bleecker, A.B. and H. Kende. 2000. Ethylene: A gaseous signal molecule in plants. Annu. Rev. Cell Dev. Biol. 16:1-18.

Bleecker, A.B. and G.E. Schaller. 1996. The mechanism of ethylene perception. Plant Physiol. 111:653-660.

Bleecker, A.B., M.A. Estelle, C. Somerville, and H. Kende. 1988. Insensitivity to ethylene conferred by a dominant mutation in Arabidopsis thaliana. Science 241:1086-1089.

Bradford, K.J. and D.R. Dilley. 1978. Effects of root anaerobsis on ethylene production, epinasty, and growth of tomato plants. Plant. Physiol 61:506-509.

Bradford, K.J. and S.F. Yang. 1980. Xylem transport of 1-aminocyclopropane1-carboxylic acid, an ethylene precursor, in waterlogged tomato plants. Plant Physiol. 65:322-326.

Brandt, A.S. and W.R. Woodson. 1992. Variation in flower senescence and ethylene biosynthesis among carnations. Hort. Sci. 27:1100-1102.

Burg, S.P. and E.A. Burg. 1967. Molecular requirements for the biological activity of ethylene. Plant Physiol. 42:144-152.

Burg, S.P. and E.A. Burg. 1968. Ethylene formation in pea seedlings: Its relation to the inhibition of bud growth caused by indole-3-acetic acid. Plant Physiol. 43:1069-1074.

Campbell, W.F., F.B. Salisbury, B. Bugbee, and S. Klassen. 2001. Comparative floral development of Mir-grown and ethylene-treated, Earth-grown Super Dwarf wheat. J. Plant Physiol. 158:1051-1060.

Corbineau, F., R.M. Rudnicki, D.M Goszczynska, and D. Come. 1995. The effect of light quality on ethylene production in leaves of oat seedlings (Avena sativa L.). Environ. Expt. Bot. 35:227-233.

Corey, K.A., A.V. Barker, and L.E. Craker. 1987. Ethylene evolution by tomato plants under stress of ammonium toxicity. HortScience 22:471-473.

Crevecoeur, M., C. Penel, H. Greppin, and T. Gaspar. 1986. Ethylene production in spinach leaves during floral induction. J. Expt. Bot. 37:1218-1224.

Field, R.J. 1981a. The effect of low temperature on ethylene production by leaf tissue of Phaseolus vulgaris L. Ann. Bot. 47:215-223.

Field, R.J. 1981b. A relationship between membrane permeability and ethylene production in high temperature in leaf tissue of Phaseolus vulgaris L. Ann. Bot. 48:33-39.

Field, R.J. and P.M. Barrowclough. 1989. Temperature-induced changes in ethylene production and implications for post-harvest physiology, $\mathrm{p}$ 191-199. In H. Clijsters et al. (eds.). Biochemical and physiological aspects of ethylene production in lower and higher plants. Kluwer Academic Publ., Dordrecht.

Finlayson, S.A., I-J.Lee, and P.W. Morgan. 1998. Phytochrome B and regulation of circadian ethylene production in sorghum. Plant Physiol. 116:17-25.

Finlayson, S.A. and D.M. Reid. 1996. The effect of $\mathrm{CO}_{2}$ on ethylene evolution and elongation rate in roots of sunflower (Helianthus annииs) seedlings. Physiol. Plantarum 98:875-881.

Gepstein, S. and K.V. Thimann 1980. The effect of light on the production of ethylene form 1-aminocyclopropane-1-carboxylic acid by leaves. Planta 149:196-201.

Gibson, J.L., B.E. Whipker, S. Blankenship, M. Boyette, T. Creswell, J.Miles, and M. Peet. 2000. Ethylene: Sources, symptoms, and prevention for greenhouse crops. N.C. State Univ. Hort. Info. Lflt. 530. 28 July 2004. http://www.ces. ncsu.edu/depts/hort/floriculture/hils/HIL530.pdf.

Grodzinski, B. 1984. Enhancement of ethylene release from leaf tissue during glycolate decarboxylation: A possible role for photorespiration. Plant Physiol. 74:871-876.

Grodzinski, B. and L. Woodrow. 1989. Ethylene and carbon dioxide exchange in leaves and whole plants, p. 271-278. In H. Clijsters et al. (eds.). Biochemical aspects of ethylene production in lower and higher plants. Kluwer Academic Publ., New York.

Gubrium, E.K., D.J. Clevenger, D.G. Clark, J.E. Barrett, and T.A. Nell. 2000 Reproduction and Horticultural performance of transgenic ethylene-insensitive petunias. J. Amer. Soc. Hort. Sci. 125:277-281.

Guzman, P. and J.R. Ecker. 1990. Exploiting the triple response of Arabidopsis to identify ethylene-related mutants. The Plant Cell. 2:513-523.

Hoffman, T. J.S. Schmidt, X. Zheng. 1999. Isolation of ethylene-insensitive mutants that are altered in pathogen susceptibility and gene-for-gene disease resistance. Plant Physiol. 119:935-949.

Hua, J., H. Sakai, S. Nourizadeh, Q.H.G. Chen, A.B. Bleecker, J.R. Ecker, an E.M. Meyerowitz. 1998. EIN4 and ERS2 are members of the putative ethylene receptor gene family in Arabidopsis. Plant Cell. 10:1321-1332.

James, J.T., T.F. Limero, S.W. Beck, L. Yang, M.P. Martin, M.L. Matney, P.A. Covington and J. F. Boyd. 1998. Toxicological assessment of air contaminants. Shuttle-Mir Sci. Prog., Phase 1A Res. Post-flight Sci. Rpt 4:111-124.

Kao, C.H. and S.F. Yang. 1982. Light inhibition of the conversion of 1-aminocyclopropane-1-carboxylic acid to ethylene in leaves is mediated through carbon dioxide. Planta 155:261-266.

Kawase, M. 1972. Effect of flooding on ethylene concentration in horticultural plants. J. Amer. Hort. Sci. 97(5):584-588

Kiss, J.Z., R.E. Edelmann, and P.C. Wood. 1999. Gravitropism of hypocotyls of wild-type and starch-deficient Arabidopsis seedlings in spaceflight studies. Planta 209:96-103.

Kiss, J.Z., W.J. Katmebe, and R.E. Edelmann. 1998. Gravitropism and development of wild-type and starch-deficient mutants of Arabidopsis during spaceflight. Physiol. Plant. 102:493-502.

Klassen, S.P. and B. Bugbee. 2002. Sensitivity of wheat and rice to low levels of atmospheric ethylene. Crop Sci. 42:746-753.

Klee, H.J. 2002. Control of ethylene-mediated processes in tomato at the level of receptors. J. Expt. Bot. 53:2057-2063.

Klee, H.J. and D.G. Clark. 2002. Manipulation of ethylene synthesis and perception: The ins and the outs. HortScience 37:450-452.

Knee, E.M., R.P. Hangarter, and M. Knee. 2000. Interactions of light and ethylene in hypocotyl hook maintenance in Arabidopsis thaliana seedlings. Physiol. Plant. 108:208-215.

Knoester, M., L.C. van Loon, J. van den Heuvel, J. Hennig, J.F. Bol, H.J.M. Linthorst. 1998. Ethylene-insensitive tobacco lacks non-host resistance against soil-borne fungi. Proc. Natl. Acad. Sci. 95:1933-1937.

Levinskikh, M.A., V.N. Sychev, T.A. Derendyaeva, O.B. Signalova, I.G. Podolsky, G.I. Padalka, S.V. Avdeev, and G.E. Bingham. 2000. Wheat cultivation from seed to seed during spaceflight. Aviakosm. Ekol. Med. 34:44-50.

Lindstrom, J.T., C.H. Lei, M.L. Jones, and W.R. Woodson. 1999. Accumulation of 1-aminocyclopropane-1-carboxylic acid (ACC) in petunia pollen is associated with expression of a pollen-specific ACC synthase late in development. J. Amer. Soc. Hort. Sci. 124:145-151.

Lurie, S., A. Handros, E. Fallick, and R. Shapira. 1996. Reversible inhibition of tomato fruit gene expression at high temperature. Plant Physiol. 110:1207-1214.

Moore, R., W.D. Clark, and D.S. Voodpich. 1998. Botany. WBC/McGrawHill, New York.

Morgan, P.W. and M.C. Drew. 1997. Ethylene and plant responses to stress. Physiol. Plant. 100:620-630.

Morgan, P.W., C.J. He, J.A. De Greef, and M.P. De Proft. 1990. Does water deficit stress promote ethylene synthesis by intact plants? Plant Physiol. 94:1616-1624.

Morgan, P.W., J.I. Sarquis, C.J. He, W.R. Jordan, and M.C. Drew. 1993. Regulation of ethylene synthesis in maize root responses to stress. Curr. Plant Sci. Biotechnol. Agr. 16:232-237

Morison, J.I.L. and R.M. Gifford. 1984. Ethylene contamination of $\mathrm{CO}_{2}$ cylinders: effects on plant growth in $\mathrm{CO}_{2}$ enrichment studies. Plant Physiol. 75:275-277.

Mortensen, L.M. 1989. Effect of ethylene on growth of greenhouse lettuce at different light and temperature levels. Sci Hort. 39:97-103.

Musgrave, M.E., A. Kuang, and S.W. Matthews. 1997. Plant reproduction during spaceflight: Importance of the gaseous environment. Planta 203: S177-S184

Narayana, I., S. Lalonde, and H.S. Saini. 1991. Water-stress-induced ethylene production in wheat. Plant Physiol. 96:406-410.

Owens, L.D., M. Liebermann, and A. Kunishi. 1971. Inhibition of ethylene production by rhizobitoxin. Plant Physiol. 48:1-4

Peng, X.X. and M. Yamauchi. 1993. Ethylene production in rice bronzing leaves induced by ferrous iron. Plant Soil 149:227-234.

Preger, R. and S. Gepstien. 1984. Carbon dioxide-independent and-dependent components of light inhibition of the conversion of 1-aminocyclopropane-1carboxylic acid to ethylene in oat leaves. Physiol. Plant. 60:187-191.

Romera, F.J., E. Alcantara, and M.D. de la Guardia. 1999. Ethylene production by Fe-deficient roots and its involvement in the regulation of Fe-deficiency stress responses by strategy I plants. Ann. Bot. 83:51-55

Roman, G.B. Lubarsky, J.J. Kieber, M. Rothenberg, and J.R. Ecker. 1995. Genetic analysis of ethylene signal transduction in Arabidopsis thaliana: Five novel mutant loci integrated into a stress response pathway. Genetics 139:1393-1409.

Sakai, H., J. Hua, Q.G. Chen, C. Chang, L.J. Medrano, A.B. Bleecker, and E.M. Meyerowitz. 1998. ETR2 is an ETR1-like gene involved in ethylene signaling in Arabidopsis. Proc. Natl. Acad. Sci. 95:5812-5817.

Salisbury, F.B. 1997. Growing Super-Dwarf wheat in space station Mir. LifeSupport Biosphere Sci. 4:155-166.

Sanders, I.O., K. Ishiharu, A.R. Smith, and M.A. Hall. 1990. Ethylene binding in rice seedlings. Plant Cell Physiol. 31:1091-1099.

Sarquis, J.I., W.R. Jordan, and P.W. Morgan. 1991. Ethylene evolution from maize (Zea mays L.) seedling roots and shoots in response to mechnical impedance. Plant Physiol. 31:1091-1099.

Schaller, G.E. and A.B. Bleecker. 1995. Ethylene-binding sites generated in yeast expressing the Arabidopsis ETR1 gene. Science 270:1809-1811.

Schwarzbach, D.A., E.J. Woltering, and M.E. Saltviet. 1991. Behavior of etiolated peas (Pisum sativum cv. Alaska) when obstructed by mechanical barrier. Plant Physiol. 98:769-773. 
Sisler, E.C. 1991. Ethylene-binding components in plants, p. 81-99. In: A.K. Mattoo and J.C. Suttle (eds.). The plant hormone ethylene. CRC Press, Boca Raton, Fla.

Sisler, E.C. and C. Wood. 1988. Interaction of ethylene and $\mathrm{CO}_{2}$. Physiol. Plant. 73:440-444.

Sisler E.C. 1979. Measurement of ethylene binding in plant tissue. Plant Physiol. 64:538-542.

Sisler E.C., and M. Serek, 1997. Inhibitors of ethylene responses in plants at the receptor level: Recent developments. Physiol. Plantarum 100: 577-582.

Smalle, J. and D. Van Der Straeten. 1997. Ethylene and vegetative development. Physiol. Plantarum 100:593-605.

Spencer, M.S. 1989. Ethylene analysis_-Tricks played by plants. In: H. Clijsters et al. (eds.). Biochemical and physiological aspects of ethylene production in lower and higher plants. Kluwer Academic Publ., Dordrecht.

Stutte, G.W. 1999. Phytochemicals: implications for long-duration space missions, p. 275-285. In: H.G. Cutler and S.J. Cutler (eds.). Biologically active natural products: Agrochemicals. CRC Press, Boca Raton, Fla.

Tarun, A.S., J.S. Lee, and A. Theologis. 1998. Random mutagenesis of 1aminocyclopropane-1-carboxylate synthase: a key enzyme in ethylene biosynthesis. Proc. Natl. Acad. Sci. 95:9796-9801.

Tibbitts, T.W., K.E. Cushman, X. Fu, M.A. Anderson, and R.J. Bula. 1998. Factors controlling activity of zirconia-titania for photocatalytic oxidation of ethylene. Adv Space Res. 22:1443-1451.

Thomma, B.P.H.J., K. Eggermont, K.F.M.J. Tierens, and W.F. Broekaert. 1999. Requirement of functional ethylnene-insensitive 2 gene for efficiency resistance of Arabidopsis to infection by Botrytis cinerea. Plant Physiol. 121:1093-1101.

Tong, C.B.S. and S.F. Yang. 1987. Chilling-induced ethylene production by beans and peas. J. Plant Growth Regulat. 6:201-208.

Tonutti, P. and A. Ramina. 1991. Oxygen concentration and ethylene production in roots and leaves of wheat: Short term reaction in air after anoxic and hypoxic treatments. Physiol. Plantarum 81:295-300.

Vangronsveld, J., H. Clijsters, and M. Van Poucke. 1988. Phytochrome-controlled ethylene biosynthesis of intact etiolated bean seedlings. Planta 174:19-24.

Weckx, J. and M. Van Poucke. 1989. The effect of white light on the ethylene biosynthesis of intact green seedlings, p. 279-290. In: H. Clijsters et al. (eds.). Biochemical and physiological aspects of ethylene production in lower and higher plants. Kluwer Academic Publ., Dordrecht.

Wheeler, R.M., B.V. Peterson, J.C. Sager, and W.M. Knott. 1996. Ethylene production by plants in closed environment. Adv. Space Res. 18:193-196.

Wilkinson, J.Q., M.B. Lanahan, D.G. Clark, A.B. Bleecker, C. Chang, E.M. Meyerowitz, and H.J. Klee. 1997. A dominant mutant receptor from Arabidopsis confers ethylene insensitivity in heterologous plants. Nature Biotechnol. 15:444-447.

Wu, M.J., L. Zacarias, and M.S. Reid. 1991. Variation in the senescence of carnation (Dianthus caryophyllus L.) cultivars. II. Comparison of the sensitivity to exogenous ethylene and of ethylene binding. Scientia Hort. 48:109-116.

$\mathrm{Xu}$, C.C. and Z. Qi. 1993. Effect of drought on lipoxygenase activity, ethylene and ethane formation in leaves of soybeans plants. Acta Bot. Sin. 35(Supp1.):31-37.

Yamauchi, M. and X.X. Peng. 1995. Iron toxicity and stress-induced ethylene production in rice leaves. Plant and Soil 173:21-28.

Yang, S.F. 1985. Biosynthesis and action of ethylene. Proceedings for the Symposium on ethylene in postharvest biology and technology of horticultural crops. HortScience 20:40-45. 